UDC $581.45 / .46: 582.573 .76$

O. V. ZARICHANSKA ${ }^{1}$, S. M. MARChYShYN ${ }^{2}$, V. P. RUdenKo ${ }^{3}$, O. V. GAMULYA ${ }^{3}$

${ }^{1}$ Vinnytsya National Memorial Medical University named after M. I. Pirogov

${ }^{2}$ Ternopil State Medical University named after I. Ya. Horbachevsky

${ }^{3}$ National University of Pharmacy

\title{
ANATOMY INVESTIGATION OF THE FLOWER AND THE LEAF OF HYBRID DAYLILY (HEMEROCALLIS HYBRIDA VAR. “STELLA DE ORO”)
}

The investigation of anatomy structure of the flower and the leaf of hybrid daylily of "Stella De Oro" variant were performed for the first time and microdiagnostic features, which can be used for identification of the investigated plant raw materials were determined. The obtained results were employed in development of quality control methods for new medicinal plant raw materials.

Key words: flower; leaf; microscopic features; hybrid daylily of "Stella De Oro" variant

\section{INTRODUCTION}

Species of Hemerocallis L. genus are employed in gardening as ornamental decorative-flowering plants, and in North America and the Far East they have medical value. Aqueous and alcoholic extracts from daylilies' flowers and leaves are recommended for the treatment of cardiovascular diseases, as sedative and anti-inflammatory remedies [4]. Highly decorative varieties - cultivars or variants - are widespread in many countries.

Variant Hemerocallis hybrida "Stella De Oro" is a perennial herbaceous plant with a compact vertically oriented rhizome with storing modified roots (pits); leaves are green, up to $35 \mathrm{~s} . \mathrm{m}$ in length and $1.5 \mathrm{~s} . \mathrm{m}$ in width. Thin 40-60 s.m tall flower stalks bear 2-5 golden-yellow flowers with a diameter up to 7 s.m, which open gradually. In Ukraine a flowering period occurs in July. From late September until the first frosts, re-blooming is typical. The anther is yellow. Fruit is triangular fruitcase. Seeds are small and black. Mostly seeds are not developed. The species are distributed only in culture, widely used in ornamental gardening. Plants are propagated vegetatively whereas hybrid forms grown from seeds lose their decorative qualities.

\section{MATERIALS AND METHODS}

Macro- and microscopic features of flower and leaf of hybrid daylily's (Hemerocallis hybrida var. "Stella De Oro") were the targets of the investigation. The plant raw materials were collected in July during the period of total flowering. For the microscopic analysis the plant raw

(c) Zarichanska O. V., Marchyshyn S. M., Rudenko V.P., Gamulya O. V., 2016 materials fixed in mixture "ethyl alcohol-water-glycerol" $(1: 1: 1)$ were used. Microscopic analysis was performed in accordance with common requirements [1, 3] using electronic microscope $M S$ 10. Micro photos were taken with the camcorder Samsung PL 50.

\section{RESULTS AND DISCUSSION}

Anatomical structure of the flower of hybrid daylily of "Stella De Oro" variant

The petal. The fimbriated uni- and multicellular trichomes are observed at the limb's epidermis of flower's petal. Cells of internal (upper) epidermis of petal's limb are parenchymatous, polygonal, straightly walled, with thin irregularly thickened cell walls and covering papillar hairs. Cell-idioblasts filled with raphids (calcium oxalate's needle crystals) are found. The stomatal apparatus is anomocytic. Conductive elements are represented by spiral and annulate vessels. In the central part near the edge of petal cells are parenchymatous, polygonal, with straight walls, closely to the center of the petal cells are prosenchymatous, elongated along the petal's axis, fusiformed of approximately rectangular. The lower part of petal near the unguis is represented by prosenchymatous, fusiformed (obliquely truncated) cells with straight walls. Internal epidermis of unguis is formed by prosenchymatous cells; closely to the base of unguis cells are parenchymatous, polygonal. The stomatal apparatus is of tetracytic type. Cell-idioblasts filled with calcium oxalate's needle crystals (raphids) frequently occur.

External (lower) epidermis of petal is represented by parenchymatous polygonal cells with straight and uniformly thickened walls. The stomatal apparatus is of anomocytic type. Epidermal cells have papillar hairs; cell- 




a



C

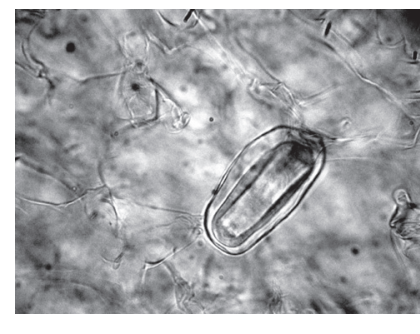

d

Fig. 1. Cells of the internal (upper) side of the petal's limb: a - parenchymatous cells; $b$-stoma of anomocytic type; $c$ - papillar trichomes on epidermis; $d$ - cell-idioblast filled with raphids



a

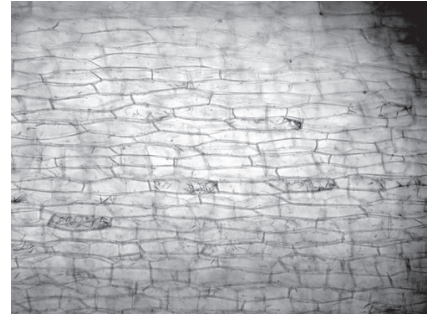

b

Fig. 2. Cells of the internal (upper) side of the petal's central and lowers parts: a - parenchymatous epidermal cells on periphery of petal; $b$ - prosenchymatous epidermal cells in the middle zone of the petal



a

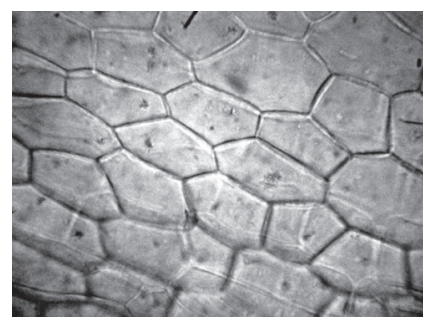

$\mathrm{b}$

Fig. 3. Internal epidermis of corolla's: a - prosenchymatous cells; $b$ - parenchymatous polygonal cells near the base of corolla

idioblasts are present. Central and lower external parts of petal in the middle are represented by prosenchymatous cells; at the periphery (closely to the edge) cells are parenchymatous, polygonal, with thin and straight walls.

The unguis: epidermis is small-cellular. Basic parenchyma consists of parenchymatous, rounded, differentsized, thin-walled cells. Parenchyma is not differentiated. Conductive fibrovascular bundles are arranged in a circle; bundles are closed collateral (side-by-side located phloem and xylem, where phloem occupies the external part of the bundle and xylem occupies the internal part). Raphids are present. Main micro diagnostic features of the corolla of hybrid daylily of "Stella De Oro" variant are represented on the Fig. 1-5.

The stamen. Epidermal cells of stamen filament are parenchymatously-prosenchymatous. Basic tissue of filament consists of parallel cells, one unbranched fibrovascular bundle is situated in the middle. Cells with raphids are present. The stomatal apparatus is of anomocytic type. The anther: cells are located under the epidermis endo- thecium having tape-shaped thickness. Cells of anther's epidermis are prosenchymatous, slightly anfractuous, uniformly thickened. Main micro diagnostic features of the stamen of hybrid daylily of "Stella De Oro" variant are represented on the Fig. 6.

The ovary. The ovary has three nests (gynoecium is cenocarpous - syncarpous). At the cross section through the ovary carpels are distinctively observed. In parenchyma idioblasts with raphids are present. Conductive system consists of dorsal and ventral bundles. Micro diagnostic features of the ovary of hybrid daylily of "Stella De Oro" variant are represented on the Fig. 7.

Anatomical structure of the leaf of hybrid daylily of "Stella De Oro" variant

The leaf blade is amphystomatal (stomas are observed on the both sides of the leaf blade). Cells of upper and lower leaf blade's epidermis are prosenchymatous, rectangular (quadrangular or pentagonal), straight-walled with uniformly thickened walls. Upper epidermis is covered with wax layering in the form of different sized 


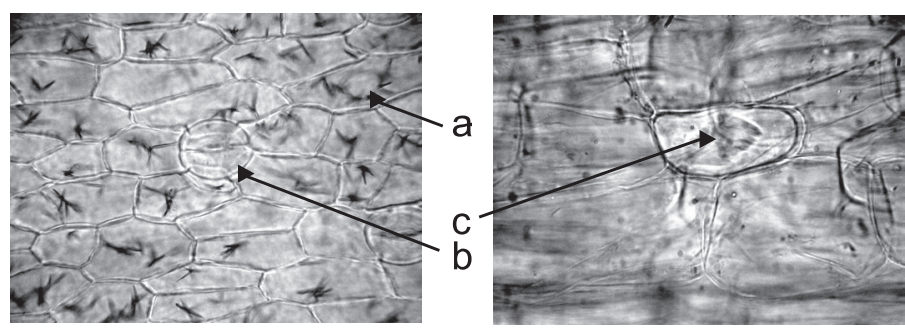

Fig. 4. External (lower) epidermis of the petal's limb (general view): a - parenchymatous polygonal cells; $b$ - stoma of anomocytic type; $c$ - cell-idioblast filled with raphids
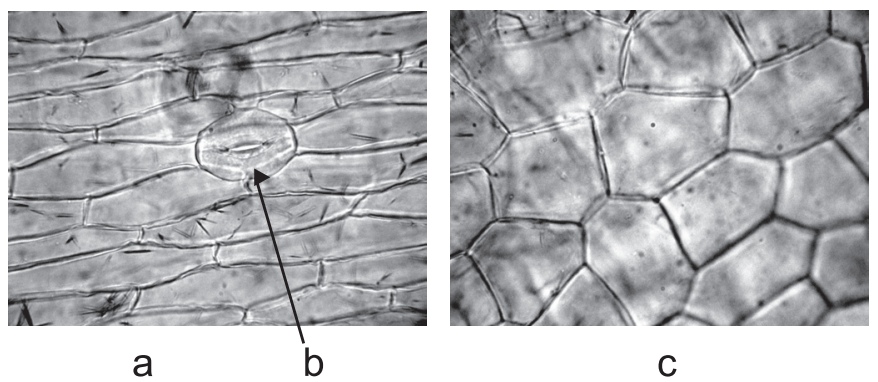

Fig. 5. Central and lower parts of external (lower) side of the petal: a-prosenchymatous cells in the middle of the petal; $b$-stoma of anomocytic type; $c$ - parenchymatous cells at the periphery of the petal
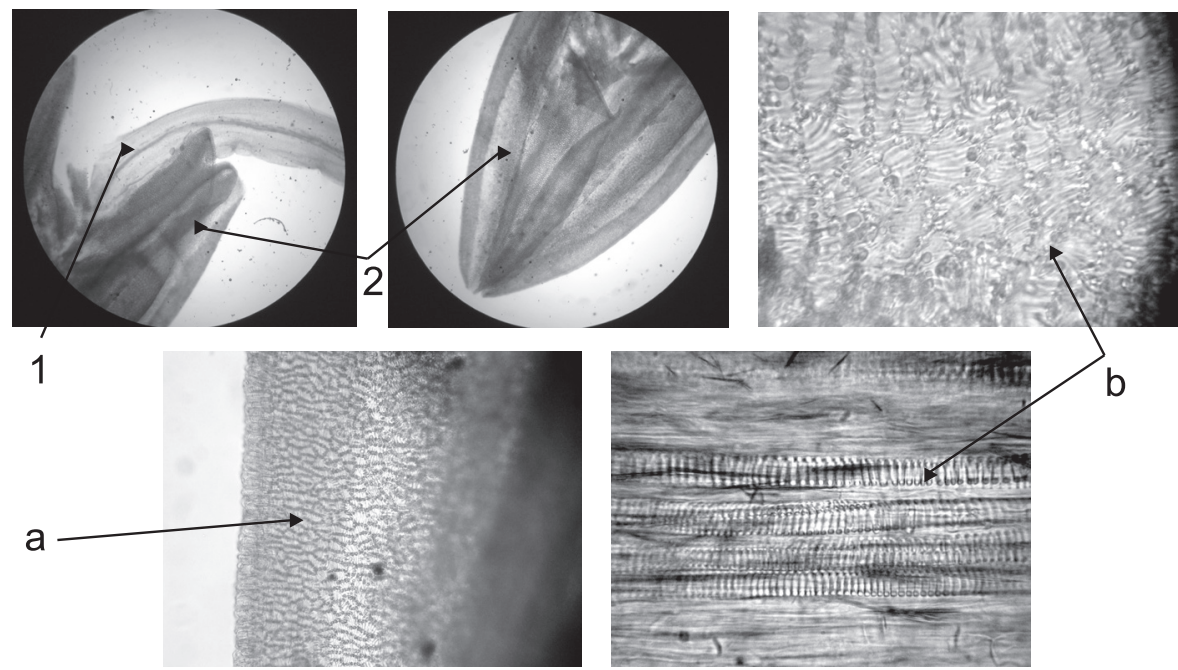

Fig. 6. Stamen: 1 - stamen filament; 2 - anther; $a$-epidermal cells of the anther; $b$ - endothecium

flakes. Cells that are situated closely to the edge of the leaf blade and above the main vein are hexagonal, narrow and elongated. In cell, the nucleus is tightly surrounded with leucoplasts is noticeable. The cavities of separate cells are filled with dark brown granular contents. Stomata are absent or single; there are 4 subsidiary cells, 2 of them are located on the sides and 2 - on poles of stomatic cleft; type of stomatal apparatus is tetracytic. Pubescence is absent.

Lower epidermis differs in more narrow mostly hexagonal prosenchymatous cells among which parenchymatous cells occur. Stomas are numerous, broadly elliptical, located as longitudinal rows along the leaf's axis, immersed from abaxial side. Amount of stomas closely to the edge of the leaf blade is reduced. Type of stomatal apparatus is tetracytic. Cells with brownish contents are less common. At the edge cells have the formations of epidermis in the form of serrations. The cells of the lower epidermis have papillary formations that are seen in crosssection.

Marginal cells and adjacent those cells of two layers of epidermis from both sides of leaf blade have more thickened walls and form short papillar outgrowths with lump-like layers with wax fragments. Papillar outgrowths are typical also for the medial epidermal cells of main vein from the lower side of leaf blade.

On enlightened preparations from the surface view in leaf parenchyma cell-idioblasts filled with raphids are observed.

Main micro diagnostic features are determined after the investigation of micro preparation from leaf of hybrid daylily of "Stella De Oro" variant from the surface view are represented on the Fig. 8. 


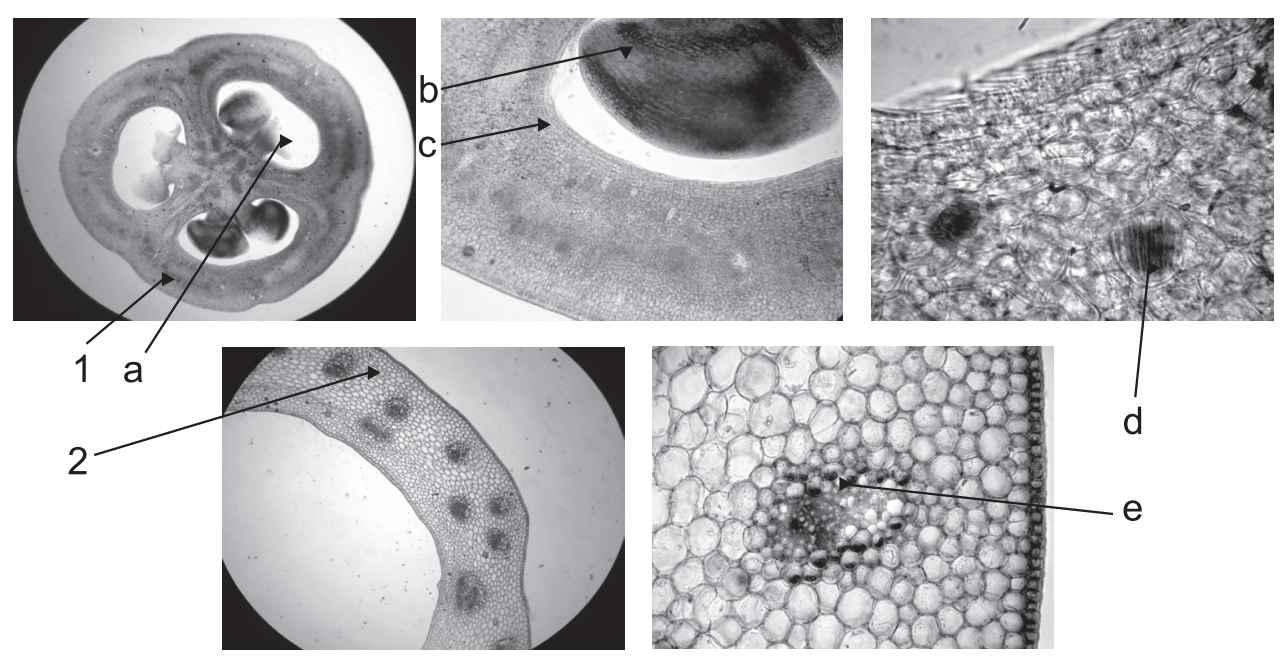

Fig. 7. Ovary and the hypanthium: 1 - gynoecium; $a$ - carpels; $b$-ovule; c-parenchyma; $d$-cell-idioblast filled with raphids; 2 - hypanthium; $e$-fibrovascular bundle

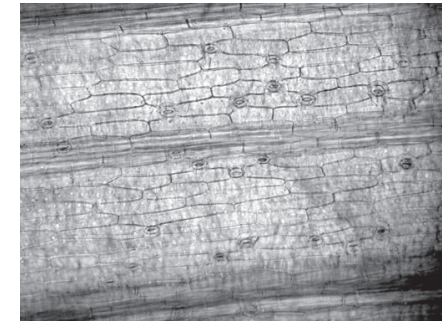

1

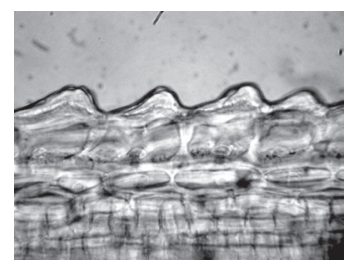

a

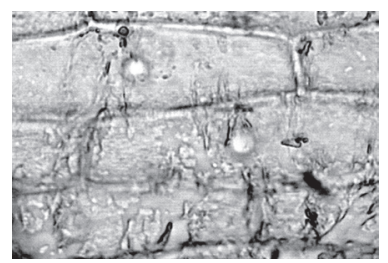

b

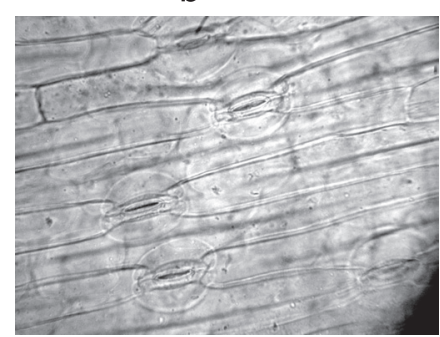

4



2

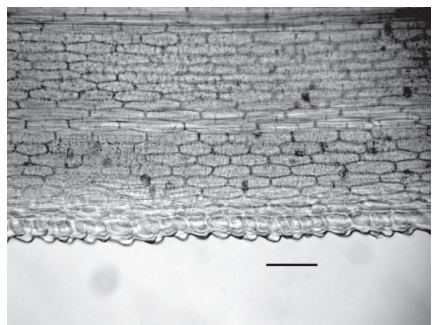

3

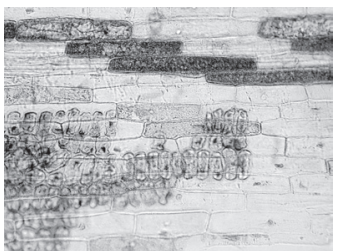

C

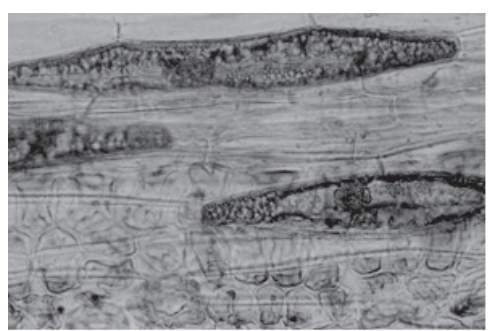

5

Fig. 8. Epidermis of the leaf (from the surface view): 1 - upper epidermis (common view);

2 - stomas of tetracytic type; 3 - leaf edge; a - serrated outgrows of epidermis at the leaf edge; $b$ - wax layering on the upper epidermis; $c$ - cells of upper epidermis with brown contents; $d$ - cell-idioblast filled with raphids; 4 - lower epidermis (common view); 5 - cells of lower epidermis with brown contents 


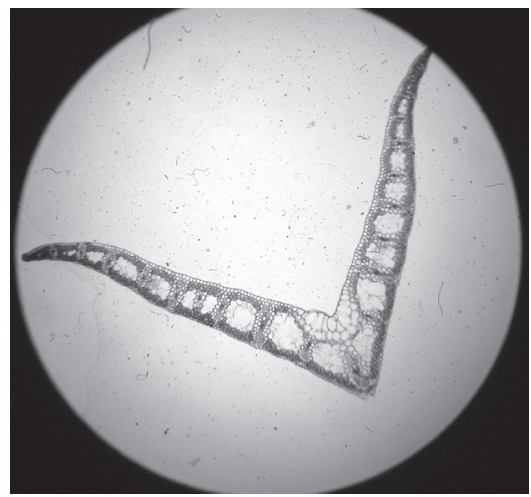

1

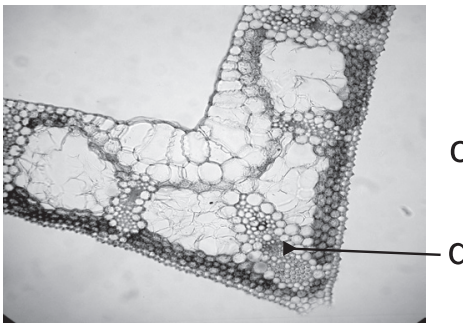

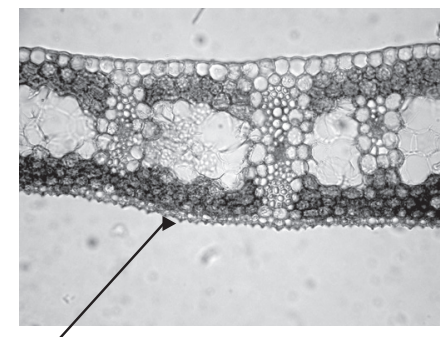

a

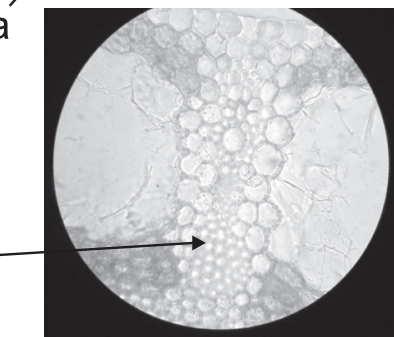

$b$

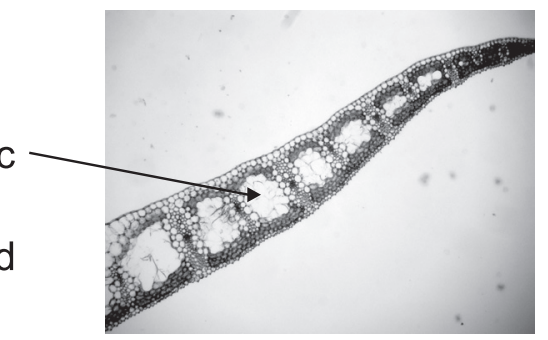

Fig. 9. Leaf of hybrid daylily (cross section view): 1 - common view of the cross section: $a$ - epidermis; $b$ - mesophyll; $c$-airenchyma; $d$-fibrovascular bundle of the main vein

On the cross section of the leaf epidermal cells are commonly isodiametral, have convex, triangularly pointed or blunt outer wall. Cells of upper epidermis closely to channeled main vein are gradually enlarged; the biggest cells are located in the middle.

On the cross section mesophyll is undifferentiated, is represented by thin-walled round-shaped cells. Fibrovascular bundles are well developed, collateral. The most developed bundles pass from adaxial side to abaxial and divide mesophyll into segments. Mechanical tissue is developed because of the bundles. Smaller bundles do not exceed mesophyll border. Around the bundle the cover from parenchyma is developed. Air spaces are situated between conductive bundles. Over the marginal vein from the adaxial side bladder-like cells are present; below those cells, the layer of large-cellular parenchyma is placed.

The type of anatomical structure of leaf blade according to the location of assimilative tissue is isolateral. Chlorenchyma is spongy and compact. Commonly three rows of chlorenchyma cells adjoin to the upper epidermis, a lot of those cells are elongated, as usually are oriented across the leaf axis; Such cells are situated along epidermis on the cross section. Two rows of chlorenchyma cells adjoin to the lower epidermis, it's cells are both elongated and rounded or slightly lobed. Chlorenchyma in one or occasionally in two rows encircles edges of conductive bundles of main and lateral veins; chlorenchyma is located under or over some of veins and fill in the ledge of main vein and the leaf edges. Upper and lower zones of chlorenchyma between veins border with wide area of large parenchymatous cells without content with thin, bent, partially deformed or damaged walls.

Main vein has one bundle, it's shape on the cross section is narrowed triangular with blunt tip. The bundle of main vein is elongated, from the phloem side borders with multilayered elliptical cords of sclerenchyma. Sclerenchyma in from one to three rows embraces xylem. Xylem vessels are not numerous, occur as ringed and spiral. Cover from parenchyma of bundle with larger cells near the xylem border with upper epidermis. Bundles of side veins are elongated, located closely to epidermis, have less developed mechanical tissue and better expressed cover. Bundles that are situated closely to the edge are rounded, embraced with large-celled cover.

Microscopic features are typical for the cross section of the leaf of hybrid daylily of "Stella De Oro" variant are represented on the Fig. 9.

\section{CONCLUSIONS}

1. Anatomical features of the flower and the leaf of hybrid daylily (Hemerocallis hybrida var. "Stella De Oro") were investigated for the first time. Main micro diagnostic features of new promising medicinal plant raw materials were determined.

2. For the anatomical structure of the leaf of hybrid leaf blade), papillar outgrowths at the edge daylily of 
"Stella De Oro" variant the following diagnostic features are the distinctive anatomy of:

- Petal's cells (parenchymatous epidermal cells at the margin of petal and prosenchymatous cells in the middle of petal, stomas of anomocytic type, papillar hairs on epidermis, cell-idioblasts filled with raphids).

- Stamens (parenchymatously-prosenchymatous epidermal cells of stamen filament, parenchymatous cells of basic tissue of stamen filament, cells with raphids, the stomatal apparatus of anomocytic type, cells of anther's epidermis are prosenchymatous, slightly anfractuous, uniformly thickened.

- Ovary (ovary with three nests, gynoecium is cenocarpous - syncarpous).

3. Anatomical structure of the leaf of hybrid daylily of "Stella De Oro" variant is characterized by isolateral type of leaf blade, tetracytic type of stomatal appararus (stomas are situated tightly on the lower side of the leaf), the presence of wax layering on the upper epidermis of the leaf and cells with brown con- tent (mostly located on the upper side of the of the leaf and along the main vein from the lower side of leaf blade, cell-idioblasts filled with raphids.

\section{REFERENCES}

1. Барыкина Р. П. Основы микротехнических исследований в ботанике: [справ. руководство] / [Р. П. Барыкина, Т. Д. Веселова, А. Г. Девятов и др.]. М.: Изд-во МГУ, 2000. - С. 127.

2. Державна фармакопея України / Державне підприємство «Науково-експертний фармакопейний центр». - 1-е вид. - Доп. 2. - Х.: Державне підприємство «Науково-експертний фармакопейний центр», 2008. - 620 с.

3. Сербин А. Г.Атлас по анатомии растений / А. Г. Сербин, Л. С. Картамазова, В. П. Руденко, Т. Н. Гонтовая. - Х.: Колорит, 2006. - 86 с.

4. Duke James A. Handbook of medicinal herbs / James A. Duke, Mary Jo Bogenschutz-Godwin, Judi duCellier, Peggy-Ann K. Duke. - 2-nd ed. - CRC Press LLC, 2002. - P. 246 


\section{УДК $581.45 / .46: 582.573 .76$ \\ 0. В. Зарічанська, С. М. Марчишин, В. П. Руденко, О. В. Гамуля \\ АНАТОМІЧНЕ ДОСЛІДЖЕННЯ КВІТКИ І ЛИСТКА ЛІЛІЙНИКА ГІБРИДНОГО \\ (HEMEROCALLIS HYBRIDA VAR. "STELLA DE ORO»)}

Вперше проведено дослідження анатомічної будови квітки і листка лілійника гібридного сорту «Stella De Oro» та встановлені мікродіагностичні ознаки, які можуть використовуватися для ідентифікації досліджуваної рослинної сировини. Отримані результати використані при розробці методик контролю якості на нову лікарську рослинну сировину.

Ключові слова: квітка; листок; мікроскопічні ознаки; лілійник гібридний сорту «Stella De Oro»

УДК $581.45 / .46: 582.573 .76$

Е. В. Заричанская, С. М. Марчишин, В. П. Руденко, О. В. Гамуля

АНАТОМИЧЕСКОЕ ИССЛЕДОВАНИЕ ЦВЕТКА И ЛИСТА ЛИЛЕЙНИКА ГИБРИДНОГО

(HEMEROCALLIS HYBRIDA VAR. "STELLA DE ORO»)

Впервые проведено исследование анатомического строения цветка и листа лилейника гибридного сорта «Stella De Oro» и определены микродиагностические признаки, которые могут использоваться для идентификации исследуемого растительного сырья. Полученные результаты использованы при разработке методик контроля качества нового лекарственного растительного сырья.

Ключевые слова: цветок; лист; микроскопические признаки; лилейник гибридный сорта «Stella De Oro».

Адреса для листування:

46001, м. Тернопіль, майдан Волі, 1.

Тел.+380 352 524492. E-mail: svitlanafarm@ukr.net.

Тернопільський державний медичний університет

ім. І. Я. Горбачевського 